\title{
DNA Damage, DNA Repair, Aging, and Neurodegeneration
}

\author{
Scott Maynard ${ }^{1}$, Evandro Fei Fang ${ }^{2}$, Morten Scheibye-Knudsen², Deborah L. Croteau ${ }^{2}$, \\ and Vilhelm A. Bohr ${ }^{1,2}$ \\ ${ }^{1}$ Department of Cellular and Molecular Medicine, Center for Healthy Aging, University of Copenhagen, \\ DK-2200 Copenhagen, Denmark \\ ${ }^{2}$ Laboratory of Molecular Gerontology, National Institute on Aging, National Institutes of Health, Baltimore, \\ Maryland 21224 \\ Correspondence:vbohr@nih.gov
}

Aging in mammals is accompanied by a progressive atrophy of tissues and organs, and stochastic damage accumulation to the macromolecules DNA, RNA, proteins, and lipids. The sequence of the human genome represents our genetic blueprint, and accumulating evidence suggests that loss of genomic maintenance may causally contribute to aging. Distinct evidence for a role of imperfect DNA repair in aging is that several premature aging syndromes have underlying genetic DNA repair defects. Accumulation of DNA damage may be particularly prevalent in the central nervous system owing to the low DNA repair capacity in postmitotic brain tissue. It is generally believed that the cumulative effects of the deleterious changes that occur in aging, mostly after the reproductive phase, contribute to species-specific rates of aging. In addition to nuclear DNA damage contributions to aging, there is also abundant evidence for a causative link between mitochondrial DNA damage and the major phenotypes associated with aging. Understanding the mechanistic basis for the association of DNA damage and DNA repair with aging and age-related diseases, such as neurodegeneration, would give insight into contravening age-related diseases and promoting a healthy life span.

\begin{abstract}
$A$ ging is a major risk factor for neurodegenerAation, cancer, and other chronic diseases (Hoeijmakers 2009). No single molecular mechanism appears to account for the functional decline in different organ systems in older humans; however, one dominant theory is that molecular damage, including DNA damage and mutations, accumulate over time, and that this damage has phenotypic consequences in adult organisms (Kirkwood 2005). This article discusses our cur-
\end{abstract}

rent understanding of the role of DNA repair in counteracting aging-associated disease, the mechanisms by which DNA damage leads to aging and disease, and recent efforts to use this knowledge as a basis for therapeutic approaches to prevent cancer and neurodegenerative disease. Although the focus of aging research is on understanding human aging, many pieces of the puzzle have been revealed through use of animal model systems, which are also discussed here.

Editors: S. Jay Olshansky, George M. Martin, and James L. Kirkland

Additional Perspectives on Aging available at www.perspectivesinmedicine.org

Copyright (C) 2015 Cold Spring Harbor Laboratory Press; all rights reserved; doi: 10.1101/cshperspect.a025130

Cite this article as Cold Spring Harb Perspect Med 2015;5:a025130 
S. Maynard et al.

\section{DNA DAMAGE AND DNA REPAIR PATHWAYS}

Nucleic acids, proteins, and lipids are continually damaged by physical and chemical agents. Exogenous sources of DNA damage include radiation, diet, and environmental chemicals. Endogenous sources of DNA damage include chemical instability, such as depurination, spontaneous errors during DNA replication and repair, and reactive oxygen species (ROS), as by-products of normal metabolism. ROS are thought to generate as many as 50,000 DNA lesions per human cell per day (Lindahl 1993), including base modifications, single-strand breaks (SSBs), double strand breaks (DSBs), and interstrand cross-links (ICLs). Prominent DNA repair pathways in mammalian cells are base excision repair (BER), nucleotide excision repair (NER), mismatch repair (MMR), and double-strand break repair (DSBR) (Fig. 1). BER excises mostly oxidative and alkylation DNA damage, NER removes bulky, helix-distorting lesions from DNA (e.g., ultraviolet [UV] photodimers), MMR reverses replication errors, and DSBR is specific for repairing DSBs, mainly by either error-prone rejoining of the broken DNA ends (nonhomologous end joining

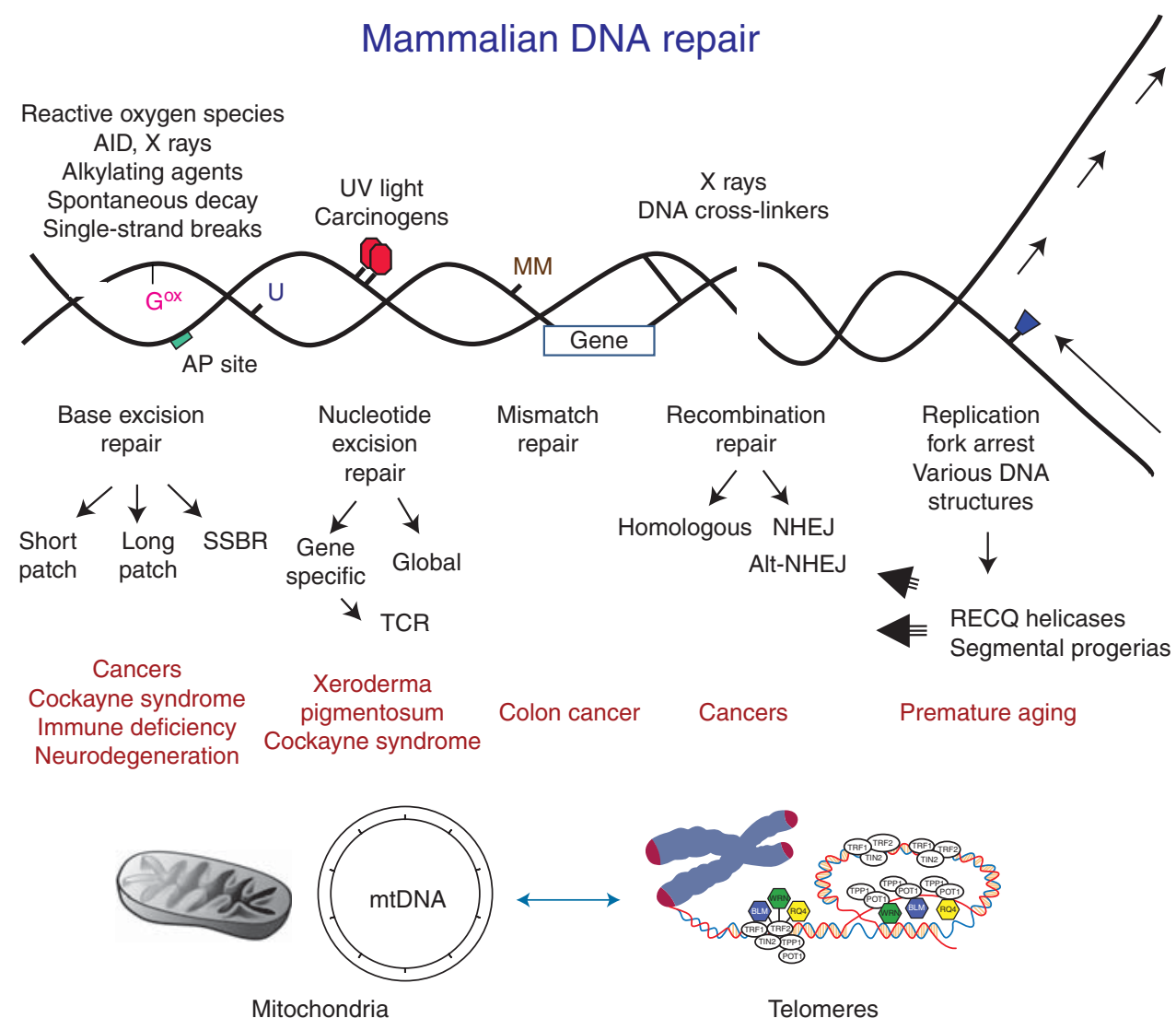

Figure 1. Mammalian DNA repair pathways. Various types of genotoxic agents result in specific DNA damage lesions repaired by specific DNA repair pathways. Defects in each repair pathway are associated with various diseases (shown in red). Subpathways are also referred to, which are described elsewhere (Khakhar et al. 2003; Iyama and Wilson 2013). The black arrows extending from "RecQ helicases" signify that these enzymes are involved in several DNA repair pathways (Croteau et al. 2014). SSBR, single-stand break repair; TCR, transcription coupled repair; Alt-NHEJ, alternative nonhomologous end-joining pathway; AID, activation-induced cytidine deaminase; MM, mismatch of DNA bases. 
[NHEJ]) or accurately repairing the DSB using information on the undamaged sister chromatid (homologous recombination $[\mathrm{HR}]$ ) (Wyman and Kanaar 2006; Iyama and Wilson 2013). Telomere maintenance is a form of targeted DNA repair that is critical for genome stability; defects in telomere maintenance are associated with cellular senescence and aging (von Zglinicki 2000; Rodier et al. 2005; Singh et al. 2011; Calado and Dumitriu 2013).

Unrepaired DNA damage can give rise to genomic instability and induce signaling cascades leading to cell senescence or cell death, which are cellular phenotypes associated with aging (Rodier et al. 2009). Indeed, the capacity to repair DNA damage is thought to decline as cells age (Moriwaki et al. 1996; Muiras et al. 1998; Li and Vijg 2012). DNA lesions can lead to mutations, some of which can be oncogenic (Bohr 2002; Maynard et al. 2009; Cha and Yim 2013). Apoptosis, senescence, and DNA repair are mechanisms that counteract oncogenesis. In addition, unrepaired DNA damage may reduce the capacity for tissue self-renewal, thus inhibiting recovery from acute stress or injury (Rossi et al. 2007). The genetic integrity of stem cells is especially important. Embryonic stems cells (ESCs) have the capacity to differentiate into all cell types, including germ cells; thus, any genetic alterations that are not corrected can compromise the genome stability and functionality of entire cell lineages. Adult stem cells are important for the long-term maintenance of tissues throughout life (Kenyon and Gerson 2007). Indeed, stem cells appear to be very proficient at DNA repair (Maynard et al. 2008; Rocha et al. 2013).

\section{NEURODEGENERATIVE DISEASE AND PREMATURE AGING}

Mitochondrial DNA (mtDNA) damage, mitochondrial dysfunction, and defects in BER can adversely affect neuronal functions, thus increasing the risk of neurodegenerative disease (de Souza-Pinto et al. 2008; Fernandez-Checa et al. 2010; Wang and Michaelis 2010). In fact, neurological dysfunction is found in individuals and mouse models with genetic errors in
DNA repair genes (McKinnon 2009; Jeppesen et al. 2011). This is consistent with accumulating evidence that DNA repair pathways and other components of the DNA damage response play a role in preventing neuropathology (Fishel et al. 2007; Rulten and Caldecott 2013; Madabhushi et al. 2014). Oxidative damage to neuronal cells may be an important component of neurodegeneration, as suggested by reports that BER is important in preventing neurodegeneration (Liu et al. 2011; Bosshard et al. 2012; Sheng et al. 2012; Canugovi et al. 2013; Lillenes et al. 2013). The mammalian brain consumes oxygen at a relatively high rate, leading to high exposure of neurons to the associated ROS byproducts; if antioxidants are depleted in the brain, neurons become susceptible to ROS-induced DNA damage (Sai et al. 1992; Hirano et al. 1996; Kaneko et al. 1996; Nakae et al. 2000; Barja 2004).

Defects in DNA repair contribute to genomic instability, which increases with age. Interestingly, age1 and other long-lived mutants of the nematode Caenorhabditis elegans show increased DNA repair capacity, whereas DNA repair-deficient nematodes have a significantly shorter life span, supporting the hypothesis that DNA repair capacity influences longevity (Hyun et al. 2008). In humans, premature aging and early death are characteristics of several rare heritable diseases linked to defects in DNA repair or the processing of DNA damage (Brosh and Bohr 2007; Vijg 2008; Campisi and Vijg 2009; Martin 2011). In many cases, genetically modified mice with comparable defects in DNA repair show similar disease phenotypes that resemble normal aging, suggesting a causal relationship between DNA repair defects and premature aging (de Boer et al. 2002; Andressoo et al. 2006; Garinis et al. 2008; Gredilla et al. 2012). Human diseases of premature or accelerated aging include Werner syndrome (WS), Cockayne syndrome (CS), and Hutchinson-Gilford progeria syndrome (HGPS). All three are termed "segmental progerias" because patients prematurely display some but not all features of normal aging. WS is the most well-characterized premature aging disorder in humans and appears to most closely resemble an acceleration of normal 
aging (Goto 1997; Kyng et al. 2009). The Werner protein (WRN), mutated in WS patients, is a member of the highly conserved RecQ helicase family, which consists of enzymes that unwind double-stranded DNA and play important roles in DNA replication, recombination, and repair (Rossi et al. 2010). Several studies implicate RecQ helicases in critical processes of DNA replication and repair that influence genomic stability (Sun et al. 1998; Fry and Loeb 1999; Machwe et al. 2006; Bachrati and Hickson 2008; Croteau et al. 2014). CS is a premature aging disorder associated with specific defects in DNA repair and transcription. CS patients show severe developmental and neurological abnormalities (Jeppesen et al. 2011). Some clinicians view CS as a distinct early aging phenotype (Weidenheim et al. 2009; Natale 2011). Mutations in CSB (Cockayne syndrome complementation group B) account for $\sim 80 \%$ of CS cases, with the majority of remaining CS patients carrying mutations in the CSA gene. In addition to its wellestablished role in transcription-coupled NER, CSB also plays a role in BER and maintenance of mitochondrial function (Stevnsner et al. 2008; Osenbroch et al. 2009; Aamann et al. 2010; Scheibye-Knudsen et al. 2012). HGPS is commonly caused by a point mutation in the lamin $\mathrm{A}$ gene, leading to a dysfunctional truncated version of the nuclear scaffolding protein lamin A (this aberrant protein is termed progerin). Unlike WS and CS, the defect is not presumed to be directly associated with a defect in DNA repair or processing; however, recent studies suggest that lamin A promotes DNA repair, especially DSBR (Redwood et al. 2011; Gonzalo 2014).

\section{THEORIES OF AGING}

Aging is often defined as the accumulation of deleterious biological changes over time, which increases an organism's vulnerability to disease and renders it more likely to die. However, the causal relationship between the biological changes that occur with time and aging is not fully understood. Numerous theories of aging have been suggested, but none of these fully explain all aspects of aging. In this section, we summarize common theories of aging (Fig. 2).
These processes are not mutually exclusive, they may interact in complex ways, and they lead to DNA damage accumulation.

\section{Evolutionary Theories of Aging}

The programmed (adaptive) theory of aging states that a genetic program drives the aging process, and that organisms have evolved mechanisms to limit the organism's life span beyond a specific age to benefit subsequent generations. In contrast, many other theories state that aging is a stochastic or random process, with no specific evolutionary value or force. As to why we age, the evolutionary theory of aging states that aging is the result of a decline in the force of natural selection (Tosato et al. 2007; Robert et al. 2010; Goldsmith 2012). One proposed mechanism (or subtheory) of the evolutionary theory is referred to as mutational accumulation, which suggests that the evolutionary effects of adverse events decline following the peak of reproduction (Charlesworth 2001; Martin 2011). Another proposed mechanism is referred to as antagonistic pleiotropy (or tradeoff ). It suggests that gene variants that enhance reproductive fitness early in life show deleterious effects later in life, after the peak of reproduction (Ljubuncic and Reznick 2009; Martin 2011). Yet another evolutionary theory is the socalled disposable soma theory, which proposes that the failure to repair accumulated stochastic damage is a consequence of evolved limitations in somatic maintenance and repair functions. It predicts that organisms with expected high survival and low reproductive rates should use more metabolic resources in protecting their soma than organisms that expect a shorter life span and to reproduce rapidly (Kirkwood 2005). It has been suggested that the life-span extension induced by caloric restriction may represent the adaptive readjustment of the organism's metabolic resources away from growth and reproduction and toward somatic maintenance (Shanley and Kirkwood 2000). These theories suggest that the cumulative effects of lateacting deleterious changes contribute to species-specific rates of aging (Brunet-Rossinni and Austad 2004). 
DNA Damage and Aging
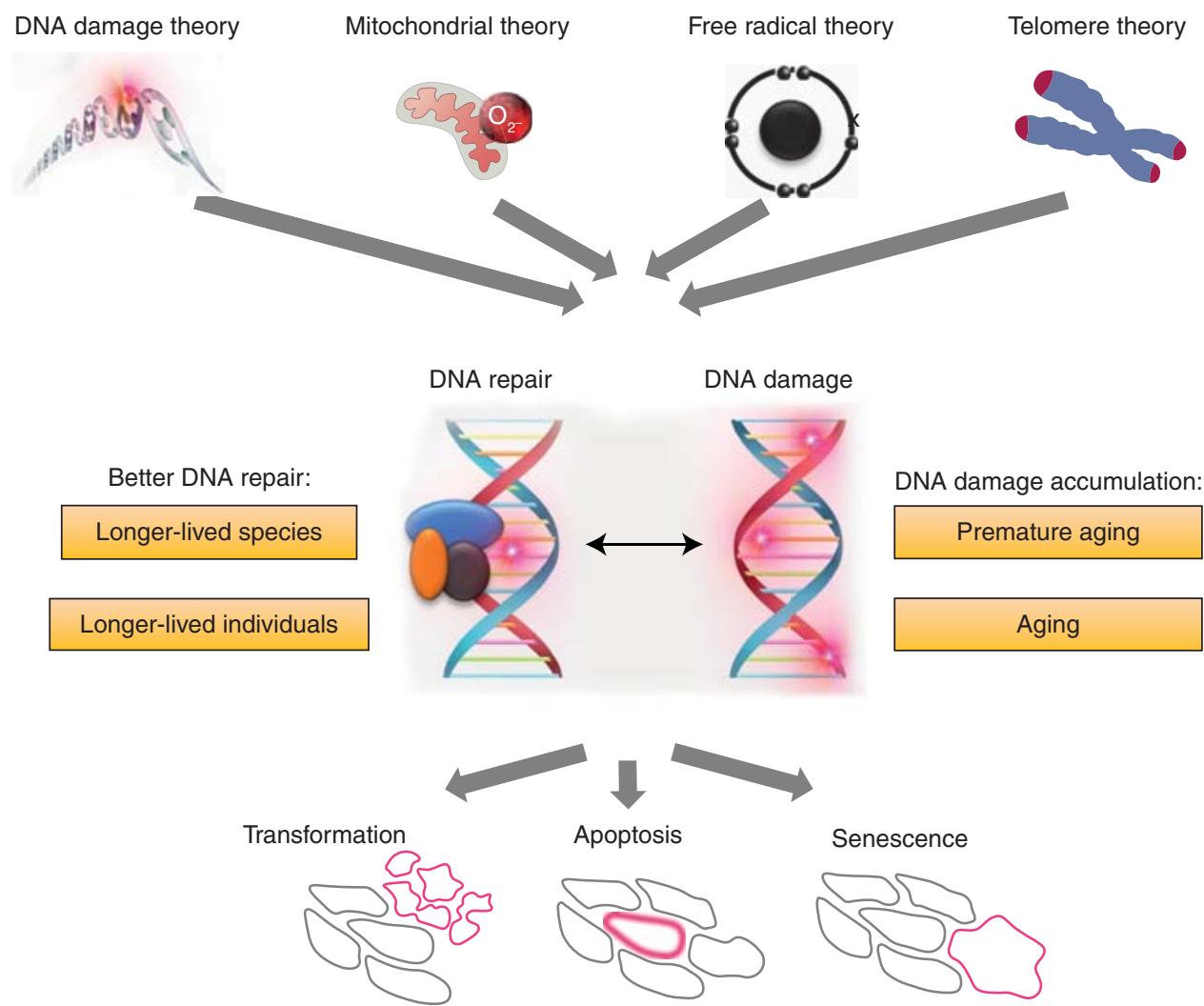

Figure 2. Four major theories of aging. Each theory has DNA damage accumulation and DNA repair as a major component. A variety of evidence, not always consistent (Moskalev et al. 2013), indicates that DNA damage accumulation is associated with aging.

\section{DNA Damage/Repair Theory of Aging}

This theory states that unrepaired DNA damage contributes to genomic instability and the aging process (Fig. 2). Although which specific DNA lesions contribute to aging is still debated, ageassociated DNA damage could include DNA breaks, cross-links, and modified bases (e.g., oxidative lesions). This theory is part of a broader concept that aging results from a general loss of molecular fidelity (Hayflick 2007). In this context, it has been postulated that natural selection has allowed us to maintain optimal biomolecular fidelity through the peak period of reproductive potential. After this period, survival of the individual is superfluous to survival of the species, and molecular fidelity declines. Genomic maintenance has been described as a double-edged sword (Vijg 2014)_DNA dam- age by exogenous and endogenous sources is often not perfectly repaired, thus leading to mutations. In germline cells, these mutations drive evolutionary change through natural selection. In somatic cells of multicellular organisms, these mutations could contribute to aging.

Some DNA repair pathways, such as MMR, $\mathrm{HR}$, and NHEJ, are associated with replication, and thus are attenuated in nondividing cells, such as neuronal cells; BER, NER, and transcription-coupled repair appear to play important roles in neurons (Fishel et al. 2007; Nouspikel 2007; Iyama and Wilson 2013). Accumulation of DNA mutations with age is accompanied by an increase in probability of tumor formation. Germline cells, and the ESCs that they originate from, may avoid the buildup of stochastic DNA damage by either more efficient DNA repair systems or replacement of cells 
S. Maynard et al.

that have lower levels of DNA damage by clonal outgrowth. Indeed, human and mouse ESCs possess more efficient repair of multiple types of DNA damage (Saretzki et al. 2004; Maynard et al. 2008; Tichy and Stambrook 2008; Momcilovic et al. 2010; Rocha et al. 2013), thereby decreasing the likelihood of passing on mutations to daughter cells.

\section{The Mitochondrial and Free Radical Theories of Aging}

The mitochondrial theory of aging postulates that accumulation of damage to mitochondria and mtDNA leads to physiological dysfunction and eventually to pathological disease (Harman 1972). It has been suggested that mitochondria also become "leaky" over time, releasing ROS that may contribute to nuclear genomic instability (Samper et al. 2003). This theory is consistent with the observation that mtDNA mutates at a much faster rate and accumulates more damage than nuclear DNA, and is further supported by the observations that mice with an error-prone mtDNA polymerase $\gamma$ age prematurely (Trifunovic et al. 2004) and that overexpression of mitochondrial-targeted catalase (an antioxidant) in mice leads to increased life span (Schriner et al. 2005).

The free radical theory of aging proposes that aging is caused by the accumulation of damage inflicted by free radicals (Park and Yeo 2013; Vina et al. 2013; Gladyshev 2014). This has obvious strong overlap with the mitochondrial theory (Fig. 2), because much of the endogenous ROS comes from imperfect ("leaky") mitochondrial respiration. There is abundant evidence for a role of mitochondrial dysfunction and ROS in age-associated diseases (Lee et al. 2010; Victor et al. 2011; Ramamoorthy et al. 2012; Lagouge and Larsson 2013; Marzetti et al. 2013; Maynard et al. 2013). Indeed, our group has recently reported associations of ROS and DNA damage with self-reported fatigue/vitality in peripheral blood mononuclear cells of human participants (Maynard et al. 2013, 2014). When aging in the various organ systems is considered, the theory that often appears is the oxidative stress/free radical theory (Cefalu 2011).
However, it has been argued that any single type of damage, such as oxidative DNA damage, is not enough to explain aging and that intervention in just one damage type will not delay organismal aging (Jin 2010; Gladyshev 2014; Liochev 2014). Perhaps this explains why antioxidant supplementation strategies, with the purpose of promoting longevity, have not been effective (Fusco et al. 2007; Vina et al. 2013; Gladyshev 2014).

\section{Telomere Theory of Aging}

Cellular senescence is triggered by erosion or improper maintenance of telomeres leading to cell-cycle exit after a certain number of cell cycles (Hayflick limit) (Hayflick 1965; Holliday 2014). Telomeric DNA and telomere-specific DNA-binding proteins form a structurally distinct domain at chromosome termini. Telomeres prevent chromosome ends from being recognized as DSBs. When telomeres shorten, cells induce a DNA damage response (Fig. 2) (Karlseder et al. 1999). Furthermore, depletion of DNA damage-response factors can result in defective telomere maintenance; for example, studies have shown that cells lacking or deficient in certain helicases display telomere attrition and/or replication defects (Crabbe et al. 2004; Sfeir et al. 2009; Ghosh et al. 2011). Human telomeric DNA includes $2-15 \mathrm{~kb}$ of tandem repeats of TTAGGG, plus a terminal 3 '-protruding G-rich single-stranded DNA (ssDNA) tail greater than 100 nucleotides long (Lin et al. 2014). The ssDNA tail folds back and invades the telomeric double-stranded DNA (dsDNA) forming a telomeric T-loop that is critical for telomere capping (Hanish et al. 1994). Telomerase is a specialized DNA polymerase that is responsible for telomere replication. The somatic expression of telomerase is insufficient to compensate for telomere loss. Even though mice have longer telomeres, telomere dysfunction is thought to contribute significantly to aging in mice. Telomerase reactivation (and telomere elongation) reverses age-related pathology in mice (Jaskelioff et al. 2011); however, early death often occurs because of tumor formation (Gonzalez-Suarez et al. 2002). DNA glycosylases are critical in the 
removal of oxidative base damage at telomeres, but they do so imperfectly, and, thus, oxidative DNA damage still accumulates in telomeres of older mice and disrupts telomere length homoeostasis (Lu and Liu 2010; Wang et al. 2010; Rhee et al. 2011). The loss of telomeres is a classic example of the imperfect homeostasis that may contribute to aging (Teplyuk 2012).

A new research area of great interest is the association between telomere shortening and mitochondrial dysfunction (Sahin et al. 2011). Although the mechanism of such "cross talk" is not yet well understood, there are examples of proteins that participate in both compartments, such as RECQL4, which interacts with human telomeric DNA (Ghosh et al. 2011) and is present in mitochondria (Croteau et al. 2012). A number of recent observations (von Zglinicki et al. 2001; Passos et al. 2007; Sahin et al. 2011) have indicated that mitochondrial dysfunction can lead to telomere attrition and vice versa.

\section{Cellular Senescence during Aging}

Stochastic damage events can lead to cellular senescence. The senescence cellular stress response is now considered one of the major drivers of aging. Consistent with this concept, in most cases, fibroblasts from patients with progeriod syndromes have accelerated senescence (van de Ven et al. 2006). Conversely, fibroblasts from long-lived Snell dwarf mice are resistant to the oxidative damage that contributes to growth arrest in vitro (Maynard and Miller 2006). Senescent cells now appear to be a major player in the aging process by the acquisition of the senescence-associated secretory phenotype, which impacts the cellular milieu; this property of senescent cells is apparently a response to genotoxic stress (Campisi and Robert 2014). Senescent cells accumulate in many tissues over time (Fig. 2) (Dimri et al. 1995; Ressler et al. 2006), indicating that their formation occurs at a faster rate than their death or removal. The senescence cellular stress response is also an important anticancer mechanism (Campisi 2013). Indeed, the tumor suppressor p53 plays an important role in the regulatory mechanisms between DNA repair, apoptosis, and senescence (Erol
2011). However, evidence indicates that senescence drives both degenerative and hyperplasic pathologies; thus, it has been proposed that the senescence response may have features that are antagonistically pleotropic (Campisi 2013). Thus, senescence appears to be another demonstration of imperfect homeostasis as a basis of aging (Teplyuk 2012). Notably, germ cells/ESCs do not undergo senescence; this is a manifestation of the germline evasion of imperfect homeostasis (Evans and Kaufman 1981; Teplyuk 2012).

\section{Stem-Cell Depletion during Aging}

Most tissues of multicellular organisms have the ability for regeneration and self-renewal, by repopulating adult stem cells; this ability declines with age. The exhaustion of stem-cell pools with age is likely a result of several of the processes discussed above, such as accumulation of DNA mutations, telomere attrition, apoptosis, and senescence (Rossi et al. 2007; Beltrami et al. 2011). Bone marrow, intestines, and other highly proliferative tissues may be particularly sensitive to loss of functional stem cells. Consequently, not all tissues in an organism age at the same rate. It has been suggested that the general reason for the decline in stem-cell pools is the tissue-dependent imperfect balance between stem-cell self-renewal and differentiation (Teplyuk 2012).

\section{MITOCHONDRIAL DYSFUNCTION AND ENERGY HOMEOSTASIS}

Mitochondria are emerging as central players in aging, neurodegeneration, and metabolic diseases (Wallace 1999; Wallace et al. 2010). This dynamic organelle is central in ATP generation through oxidative phosphorylation (OXPHOS); however, mitochondria are also involved in other processes, such as biomolecule synthesis, apoptosis, and calcium regulation. The importance of mitochondria is highlighted by the elaborate and conserved maintenance pathways that ensure proper function of this organelle (Fig. 3). These include redox regulation, mtDNA repair, and autophagy. In addition, 
S. Maynard et al.

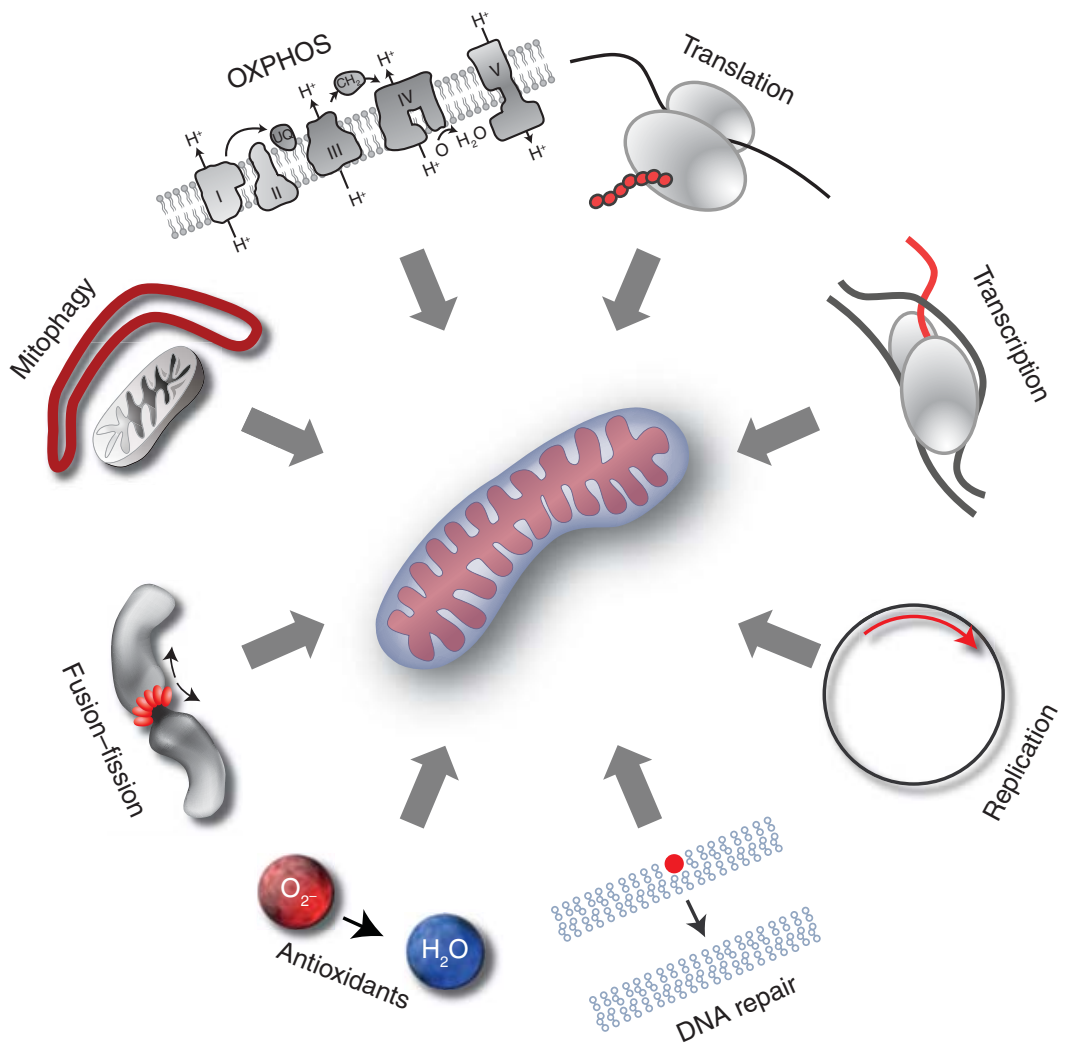

Figure 3. Pathways involved in mitochondrial maintenance.

mtDNA transcription, translation, and replication as well as proper function of OXPHOS are essential for organismal survival. Mitochondria are the primary source of superoxide, a ROS that acts both as a signaling molecule and as a source of damage. To remove ROS, aerobic organisms have an antioxidant defense system, which includes enzymes, such as superoxide dismutase, catalase, and peroxiredoxins. In addition, there are many dietary antioxidants, including glutathione, vitamin E, and vitamin C. As a feedback loop, ROS can induce the expression of antioxidant genes through transcription factors, such as PGC- $1 \alpha$ and NRF2 (Ventura-Clapier et al. 2008). If ROS is not scavenged, it can oxidize molecules in the cells, such as lipids, proteins, and DNA.

mtDNA may be particularly prone to damage in part because of its vicinity to the source of ROS, the OXPHOS machinery. Oxidatively damaged mtDNA is repaired primarily through
BER, a repair pathway that deals with singlebase damage (Gredilla et al. 2010). This repair pathway entails several enzymatic steps. First, damage is recognized by a glycosylase, such as 8-oxoguanine glycosylase 1 (OGG1), that removes the damaged base. The resultant abasic site is then recognized by the apurinic/apyrimidinic endonuclease 1 (APE1) that removes the ribose leaving a gap in the DNA strand. The gap is then subsequently filled by the mtDNA polymerase $\gamma(\mathrm{POL}-\gamma)$ and the DNA is sealed by ligase III (Gredilla et al. 2010).

If mitochondria become damaged beyond repair, the whole organelle can be degraded through a subpathway of autophagy termed mitophagy (Campello et al. 2014). Mitophagy is the process by which a double lipid bilayer is formed around the damaged mitochondria, such that it is engulfed in a vesicle, the autophagosome. The autophagosome fuses with a lysosome facilitating the degradation of its content. 
At least two mitophagy pathways can lead to mitochondrial degradation: (1) programmed mitophagy through up-regulation of the mitochondrial receptor NIX, leading to removal of all mitochondria, a pathway necessary for erythropoiesis; and (2) selective mitophagy whereby single mitochondria are degraded. The second pathway entails the initiation of mitophagy at damaged mitochondria through loss of inner mitochondrial membrane potential. Inner membrane depolarization leads to the accumulation of the kinase PINK1 on the outer membrane. PINK1 phosphorylates a number of proteins in the outer mitochondrial membrane, including MFN2 and ubiquitin, which leads to the recruitment, phosphorylation, and activation of parkin, an E3-ubiquitin ligase. Parkin ubiquitinates outer membrane proteins and facilitates the association of the mitochondria with a growing autophagosome membrane. After mitochondria become engulfed, fusion with a lysosome ensures degradation of the mitochondria (Youle and Narendra 2011; Youle and van der Bliek 2012).

It is becoming apparent that these mitochondrial-associated pathways are important for maintenance of organismal health. For example, loss of antioxidative capacity, such as vitamin E or glutathione synthase deficiency, can lead to neurodegeneration. In addition, defects in mtDNA repair can lead to neurodegeneration, as is the case for ataxia with oculomotor apraxia 1 (Sykora et al. 2011). Defects in mitophagy are associated with Parkinson's disease through mutations in PINK1 and parkin (Narendra et al. 2008). It is therefore clear that preserving mitochondrial health is important for maintaining organismal health.

Approximately one in 5000 individuals suffer from a mitochondrial disorder (Haas et al. 2007). Furthermore, several relatively common aging-related diseases appear to have a mitochondrial component. For example, mitochondrial dysfunction is a hallmark of $\beta$-amyloidinduced neural toxicity in Alzheimer's disease (Lustbader et al. 2004; Tillement et al. 2011); Parkinson's disease patients, as well as elderly individuals, have the burden of mtDNA deletions within substantia nigra neurons (Bender et al. 2006; Kraytsberg et al. 2006); cardiovascular disease is associated with increased production of ROS in mitochondria, accumulation of mtDNA damage, and progressive respiratory chain dysfunction (Madamanchi and Runge 2007; Mercer et al. 2010); and mitochondrial dysfunction characterized by reduced ATP generation appears to have a causal role in features of type 2 diabetes (insulin resistance and hyperglycemia) (Lowell and Shulman 2005). Declining mitochondrial function over the lifetime of an organism has been shown by several lines of evidence (Corral-Debrinski et al. 1992; Vendelbo and Nair 2011; Chistiakov et al. 2014). For example, it has been reported that mtDNA deletions and oxidative damage accumulate with aging (Corral-Debrinski et al. 1992; Hudson et al. 1998).

If mitochondrial dysfunction is pivotal in aging, diseases displaying accelerated aging should phenocopy the signs and symptoms seen in mitochondrial diseases. To test this hypothesis, we recently generated an online database of signs and symptoms seen in human mitochondrial disorders, www.mitodb.com (Scheibye-Knudsen et al. 2013). We then created a number of online advanced bioinformatics tools to test whether a disorder can be characterized as mitochondrial, based on its clinical signs and symptoms. We believe that this database will be useful to physicians and researchers who are studying diseases of unknown etiology. As a proof of principle, the database segregated $\mathrm{CS}$ and xeroderma pigmentosum group $\mathrm{A}$ ([XPA], a disorder with deficient nucleotide excision repair) with mitochondrial diseases. We recently reported mitochondrial and bioenergetic changes in CS cell lines and mouse tissues (Scheibye-Knudsen et al. 2012), and, thus, we had expected that this condition would cluster with mitochondrial diseases. The XPA segregation with mitochondrial diseases, however, was unexpected, and we then investigated whether XPA cells displayed altered mitochondrial properties. Both XPA-knockdown and XPA-deficient patient cells did indeed show distinct mitochondrial changes, including higher membrane potential, altered mitophagy, and higher basal oxygen and ATP consumption rates (Fang 
S. Maynard et al.

et al. 2014). Interestingly, the ataxia telangiectasia mutated (ATM) disorder also segregated with mitochondrial diseases. Recently, ATM cells that were deficient in a kinase important in the DNA damage-response cascade were shown to have higher mitochondrial membrane potential, decreased mitophagy, and higher respiration (Valentin-Vega et al. 2012). These observations suggest that www.mitodb.com is a useful tool for studying diseases linked to DNA repair defects and premature aging. Interestingly, normal aging shares many features of mitochondrial dysfunction, corroborating the mitochondrial theory of aging.

Cellular DNA damage triggers activation of the DNA damage sensor poly(ADP-ribose) polymerase 1 (PARP1) to recruit DNA repair proteins and fix the damaged DNA. PARP1 is an important protein that is involved in a variety of intracellular processes. It is one of 18 members in the PARP family and plays a major role in PARylation, the process by which PARP is covalently linked to and regulate cellular proteins. PARylation regulates a variety of intracellular processes, including DNA repair, transcription, replication, chromatin modification and cell death (Rouleau et al. 2004; Erdelyi et al. 2005). PARP1 is involved in both BER and DSBR. In addition, PARP1 appears to be involved in NER, as evidenced by the activation of this protein after UV damage, a classic NER substrate (Robu et al. 2013). In addition, PARP1 interacts with core NER proteins, such as CSB (Thorslund et al. 2005), XPA (Fan and Luo 2010; Fischer et al. 2014), and XPC (Robu et al. 2013). Although a predominantly nuclear enzyme, a portion of PARP1 proteins localizes to mitochondria and interacts with the mitochondrial protein mitofilin. The mitochondrial PARP1 may play a role in maintaining mtDNA integrity (Rossi et al. 2009).

Even though PARP1 plays a role in genome maintenance, hyperactivation of PARP1 may be detrimental to the cell. Indeed, increased activation of PARP1 has been associated with aging, abnormal metabolism, neurodegeneration, and a specific form of cell death called parthanatos. Parthanatos is a caspase-independent pathway of programmed cell death dependent on the nuclear translocation of the mitochondrial-associated apoptosis-inducing factor (AIF) (Fatokun et al. 2014). Hyperactivation of PARP1 is associated with stroke (Andrabi et al. 2011) and neurodegeneration in some premature aging disorders, such as XPA, CSB, and ATM (Fang et al. 2014). Increased PARP1 activation occurs with age in wild-type C. elegans, and DNA damage expedites this process; this is evidenced by the findings that supplementation with PARP inhibitors extends life span in wild-type and DNA repair-deficient ( $x p a-1, c s b-1)$ C. elegans (Mouchiroud et al. 2013; Fang et al. 2014; Scheibye-Knudsen et al. 2014b). Additionally, in a PARP1 knockout mouse model, there is an increased $\mathrm{NAD}^{+}$content that leads to increased SIRT1 activity and cellular metabolism in brown adipose tissue and muscle (Bai et al. 2011).

The side effects of PARP1 hyperactivation may be partially attributed to a reduction of the NAD ${ }^{+}$-SIRT1 pathway because both PARP1 and SIRT1 compete for $\mathrm{NAD}^{+}$. The consequences of lower $\mathrm{NAD}^{+}$levels because of PARP1 hyperactivation has been shown in the DNA repair defect disease model XPA (Fang et al. 2014). XPA is a $40-\mathrm{kDa}$ nuclear protein, essential for NER. XPA physically interacts with both PARP1 and PAR, and this interaction may be of importance for the repair of UV-induced damage (Fan and Luo 2010; Fischer et al. 2014). Furthermore, SIRT1 physically interacts with, and deacetylates, XPA to promote NER (Fan and Luo 2010). Because both PARP1 and SIRT1 consume $\mathrm{NAD}^{+}$on activation, PARP1 hyperactivation in XPA leads to reduced SIRT1 deacetylation because of loss of $\mathrm{NAD}^{+}$ (Fang et al. 2014; Scheibye-Knudsen et al. 2014a). PGC- $1 \alpha$ is a master regulator of mitochondrial function, and SIRT1 positively regulates the activity of PGC- $1 \alpha$ through deacetylation of this transcriptional coactivator. Loss of SIRT1 consequently leads to inactivation of PGC- $1 \alpha$ and mitochondrial dysfunction. Thus, a hitherto unrecognized impairment of the nuclear-mitochondrial signaling may be involved in the pathogenesis of XPA and other neurodegenerative DNA repair-deficient disorders.

In an effort to synthesize results of our research on mitochondrial bioenergetics and 
aging, we have developed a working model. Persistent DNA damage activates the nuclear DNAdamage response, which includes kinases and PARP. These enzymes have the capacity to consume high levels of ATP and $\mathrm{NAD}^{+}$. In an attempt to meet the ATP demands of the cell, the mitochondria become more coupled, which leads to a higher membrane potential and to lower mitophagy. However, a side effect of more coupled mitochondria is an increase in ROS production. Independently, $\mathrm{NAD}^{+}$depletion may arise from DNA damage-dependent PARP activation. Recycling $\mathrm{NAD}^{+}$from these polymers is energy demanding, but necessary for maintaining homeostatic $\mathrm{NADH} / \mathrm{NAD}^{+}$ levels and alternatively may account for the increased oxygen and ATP consumption observed in cells. It appears that deficiencies in CSB, XPA, or ATM can lead to the mitochondrial phenotypes described above; thus, uncovering common causes of mitochondrial dysfunction is an important strategy for investigating potential mechanisms of neurodegeneration in these disorders, as well as in normal brain aging (Weidenheim et al. 2009; Niedernhofer et al. 2011; Fang et al. 2014).

\section{FUTURE DIRECTIONS: INTERVENTIONS}

There are a number of proposed sites of intervention in DNA-damage accumulation, as highlighted in Figure 4. Agents that alter DNA repair may have therapeutic potential. For example, in the context of cancer chemotherapy with genotoxic drugs, inhibition of endogenous DNA repair is expected to act synergistically to increase the lethal impact on rapidly dividing cancer cells. However, genotoxic agents also damage healthy cells, and so mechanisms are needed to protect normal dividing cells from the toxic impact of the drugs. Therefore, it has been proposed that agents that stimulate DNA repair in normal cells would be useful as a component of cancer chemotherapy. Such agents might also correct deficient or defective DNA repair in other contexts, such as after acute ischemic events.

Historically, researchers have developed inhibitors of DNA repair enzymes rather than activators; however, these enzymatic pathways are highly complex, and it is not a trivial matter to enhance the overall rate of a multistep enzymatic process. One complication is that some reaction intermediates, such as certain BER intermediate products, can be toxic (Sobol et al. 2003; Rinne et al. 2004; Trivedi et al. 2005). One could envision targeting the rate-limiting step in these pathways to avoid buildup of toxic intermediates. However, although the rate-limiting step of a DNA repair pathway can be determined under defined conditions in the lab, translating this data to a living system may yield unpredictable results. Nevertheless, there is considerable interest in exploring the possibility that agents that stimulate or inhibit DNA repair can be developed as therapeutic options for cancer and other aging-associated diseases. The following paragraphs discuss some of the most promising approaches involving agents that stimulate DNA repair.

\section{BER}

Ligases (LIG) are proteins that perform the final step in the DNA repair process by sealing the ends of DNA. The prominent ligases are LIGI III and IV. LIGIII is the only ligase in mitochondria; it also operates in the nuclear compartment in complex with XRCC1 and is a component of the BER pathway. LIGIII is the only ligase essential for life and it is also a component of the mtDNA replication and DNA repair machinery (Tomkinson et al. 2013). Reduced levels and activity of LIGIII have been detected in major human neurodegenerative diseases including ataxia telangiectasia (in ATM patient cells and ATM-KO mice) (Sharma et al. 2014) and Alzheimer's disease (Canugovi et al. 2013, 2014). LIGIII activity has been reported to be the rate-limiting step of BER in mitochondria (Akbari et al. 2014). Thus, regulation of this step should be the best target for stimulation of mitochondrial BER. mtDNA repair is critical for cell survival, and stimulation of mitochondrial BER could have benefits for not only mitochondrial functions but also general cellular functions. Because LIGIII levels are decreased in ataxia telangiectasia and Alzheimer's disease, application of an LIGIII stim- 
S. Maynard et al.

Putative targets for interventions in DNA damage accumulation

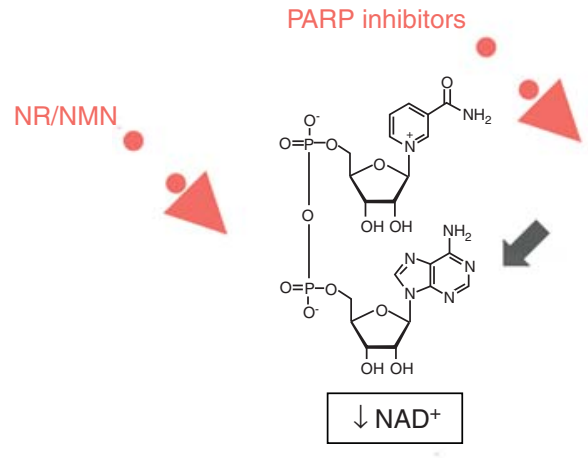

ARP inhibitors

Ketones

(-

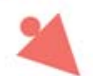

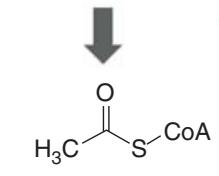

$\downarrow$ Acetyl-CoA
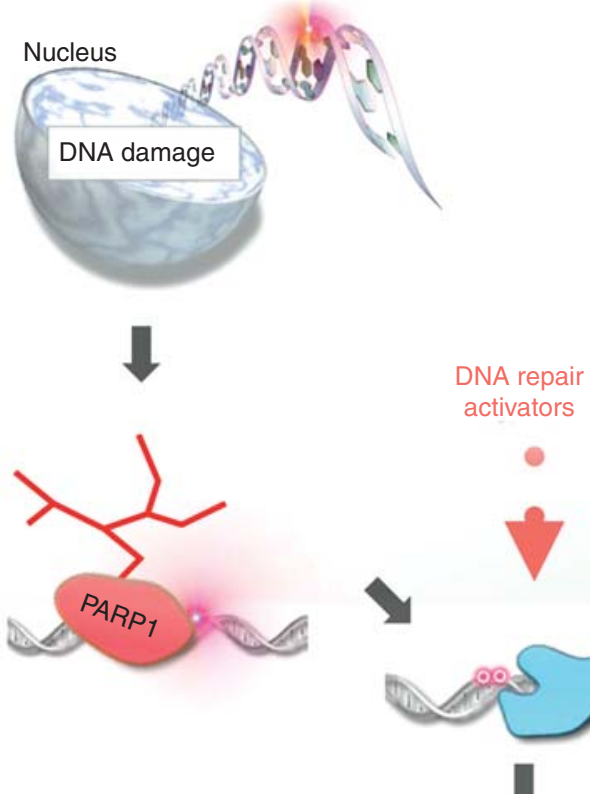

activators
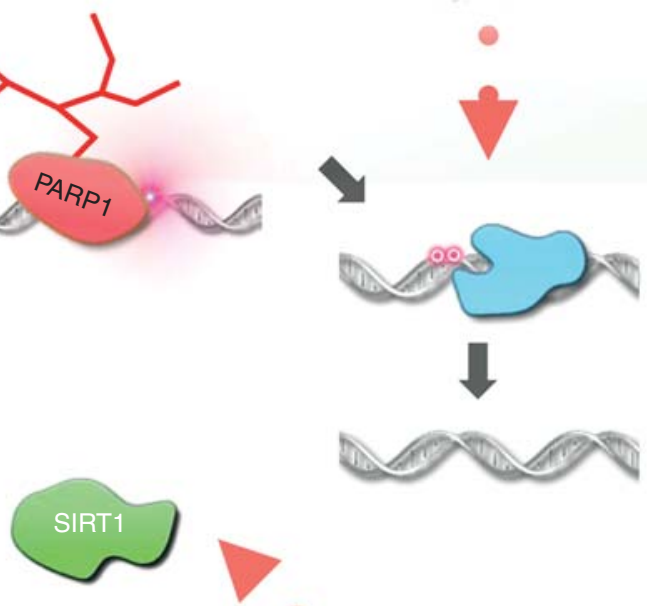

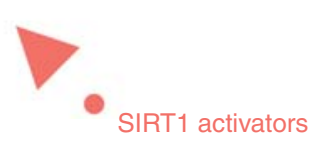

Figure 4. Possible sites of intervention that may ameliorate the consequence of DNA damage. Stimulation of DNA repair may be a feasible strategy for attenuating the effect of DNA damage. Recent research suggests that hyperactivation of the DNA damage-responsive enzyme poly(ADP-ribose) polymerase 1 (PARP1) may be involved in the aging process leading to downstream loss of SIRT1 and pleiotropic mitochondrial dysfunction. PARP1 hyperactivation leads to loss of $\mathrm{NAD}^{+}$, and reconstitution of $\mathrm{NAD}^{+}$by inhibiting PARP1 or through supplementation with $\mathrm{NAD}^{+}$precursors nicotinamide riboside (NR) or nicotinamide mononucleotide (NMN) can rescue age-associated consequences of PARP1 activation. Loss of $\mathrm{NAD}^{+}$leads to downstream metabolic dysregulation and treatment with ketone bodies may ameliorate those changes.

ulator may be particularly beneficial in these disorders. Furthermore, other diseases might also benefit from enhanced mitochondrial BER activity, such as diseases with altered antioxidant defenses and increased oxidative stress.

Although it is pharmacologically easier to target a single enzymatic reaction, a strategy could be developed to enhance the whole BER process by enhancing all enzymatic steps at the same time. One future approach to this might be to alter posttranslational modifications in the process. For example, it was observed that one protein USP47, a de-ubiquitylating en- zyme, can regulate the whole BER process, including the DNA polymerase $\beta$ enzymatic step (Parsons et al. 2011). USP47 regulation could thus be an interesting druggable target and DNA repair pathways might then be regulated at this level.

\section{PARP1}

$\mathrm{NAD}^{+}$metabolism is of great importance in health and disease as it plays a key role in many molecular processes. Boosting $\mathrm{NAD}^{+}$levels could be efficacious in antiaging studies as well 
as for the treatment of metabolic diseases and some neurodegenerative DNA repair-deficient disorders. Pharmacological approaches to increase intracellular $\mathrm{NAD}^{+}$pools include decreasing $\mathrm{NAD}^{+}$consumption by inhibition of PARPs and increasing synthesis of $\mathrm{NAD}^{+}$by supplementation with $\mathrm{NAD}^{+}$precursors, such as nicotinamide riboside (NR) and nicotinamide mononucleotide (NMN) (Fang et al. 2014; Imai and Guarente 2014). Indeed, both NR and NMN corrected mitochondrial dysfunction in XPA cells and in a $\mathrm{XPA}^{-/-} /$ $\mathrm{CSA}^{-/-}$double knockout mouse (Fang et al. 2014). Supplementation with NR may be a general strategy for improving overall mitochondrial fitness because this compound has been found to rescue respiratory chain defects and exercise intolerance in a mouse model of mitochondrial disease (Cerutti et al. 2014). Indeed, in mice, raising $\mathrm{NAD}^{+}$levels rescues age-related decline in mitochondrial-encoded OXPHOS subunits (Gomes et al. 2013).

Thus, $\mathrm{NAD}^{+}$supplementation appears to be a promising intervention. In addition, NR is stable at room temperature and is water soluble, making it a good candidate for further clinical trials in both healthy population and some specified disorders. Other current important topics/questions in this field include the possibility of synergistic effects of $\mathrm{NAD}^{+}$precursors with SIRT1 activators or $\mathrm{NAD}^{+}$precursors with PARP inhibitors, and efficacy of these compounds in both human diseases and even healthy individuals.

\section{CONCLUDING REMARKS}

Throughout this article, we have discussed the current understanding of the role of DNA repair in preventing aging-associated disease, the mechanisms by which DNA damage may lead to aging, and recent efforts to use this knowledge as a basis for therapeutic approaches to prevent aging, cancer, and neurodegenerative disease. Taken together, there is clear and compelling evidence to suggest that DNA repair mechanisms, both nuclear and mitochondrial, are essential for a long and healthy life. Regulation of DNA repair and of mitochondrial health as dis- cussed above could be a promising strategic intervention in the future.

\section{REFERENCES}

Aamann MD, Sorensen MM, Hvitby C, Berquist BR, Muftuoglu M, Tian J, de Souza-Pinto NC, Scheibye-Knudsen M, Wilson DM III, Stevnsner T, et al. 2010. Cockayne syndrome group B protein promotes mitochondrial DNA stability by supporting the DNA repair association with the mitochondrial membrane. FASEB J 24: 23342346.

Akbari M, Keijzers G, Maynard S, Scheibye-Knudsen M, Desler C, Hickson ID, Bohr VA. 2014. Overexpression of DNA ligase III in mitochondria protects cells against oxidative stress and improves mitochondrial DNA base excision repair. DNA Repair (Amst) 16: 44-53.

Andrabi SA, Kang HC, Haince JF, Lee YI, Zhang J, Chi Z, West AB, Koehler RC, Poirier GG, Dawson TM, et al. 2011. Iduna protects the brain from glutamate excitotoxicity and stroke by interfering with poly(ADPribose) polymer-induced cell death. Nat Med 17: 692-699.

Andressoo JO, Hoeijmakers JH, Mitchell JR. 2006. Nucleotide excision repair disorders and the balance between cancer and aging. Cell Cycle 5: 2886-2888.

Bachrati CZ, Hickson ID. 2008. RecQ helicases: Guardian angels of the DNA replication fork. Chromosoma 117: 219-233.

Bai P, Canto C, Oudart H, Brunyanszki A, Cen Y, Thomas C, Yamamoto H, Huber A, Kiss B, Houtkooper RH, et al. 2011. PARP-1 inhibition increases mitochondrial metabolism through SIRT1 activation. Cell Metab 13: 461-468.

Barja G. 2004. Free radicals and aging. Trends Neurosci 27: 595-600.

Beltrami AP, Cesselli D, Beltrami CA. 2011. At the stem of youth and health. Pharmacol Ther 129: 3-20.

Bender A, Krishnan KJ, Morris CM, Taylor GA, Reeve AK, Perry RH, Jaros E, Hersheson JS, Betts J, Klopstock T, et al. 2006. High levels of mitochondrial DNA deletions in substantia nigra neurons in aging and Parkinson disease. Nat Genet 38: 515-517.

Bohr VA. 2002. DNA damage and its processing. Relation to human disease. J Inherit Metab Dis 25: 215-222.

Bosshard M, Markkanen E, van LB. 2012. Base excision repair in physiology and pathology of the central nervous system. Int J Mol Sci 13: 16172-16222.

Brosh RM Jr, Bohr VA. 2007. Human premature aging, DNA repair and RecQ helicases. Nucleic Acids Res 35: 75277544.

Brunet-Rossinni AK, Austad SN. 2004. Ageing studies on bats: A review. Biogerontology 5: 211-222.

Calado RT, Dumitriu B. 2013. Telomere dynamics in mice and humans. Semin Hematol 50: 165-174.

Campello S, Strappazzon F, Cecconi F. 2014. Mitochondrial dismissal in mammals, from protein degradation to mitophagy. Biochim Biophys Acta 1837: 451-460.

Campisi J. 2013. Aging, cellular senescence, and cancer. Anпu Rev Physiol 75: 685-705. 
S. Maynard et al.

Campisi J, Robert L. 2014. Cell senescence: Role in aging and age-related diseases. Interdiscip Top Gerontol 39: 45-61.

Campisi J, Vijg J. 2009. Does damage to DNA and other macromolecules play a role in aging? If so, how? J Gerontol A Biol Sci Med Sci 64: 175-178.

Canugovi C, Misiak M, Ferrarelli LK, Croteau DL, Bohr VA. 2013. The role of DNA repair in brain-related disease pathology. DNA Repair (Amst) 12: 578-587.

Canugovi C, Shamanna RA, Croteau DL, Bohr VA. 2014. Base excision DNA repair levels in mitochondrial lysates of Alzheimer's disease. Neurobiol Aging 35: 1293-1300.

Cefalu CA. 2011. Theories and mechanisms of aging. Clin Geriatr Med 27: 491-506.

Cerutti R, Pirinen E, Lamperti C, Marchet S, Sauve AA, Li W, Leoni V, Schon EA, Dantzer F, Auwerx J, et al. 2014. $\mathrm{NAD}^{+}$-dependent activation of Sirt 1 corrects the phenotype in a mouse model of mitochondrial disease. Cell Metab 19: 1042-1049.

Cha HJ, Yim H. 2013. The accumulation of DNA repair defects is the molecular origin of carcinogenesis. Tumour Biol 34: 3293-3302.

Charlesworth B. 2001. Patterns of age-specific means and genetic variances of mortality rates predicted by the mutation-accumulation theory of ageing. J Theor Biol 210: $47-65$.

Chistiakov DA, Sobenin IA, Revin VV, Orekhov AN, Bobryshev YV. 2014. Mitochondrial aging and age-related dysfunction of mitochondria. Biomed Res Int 2014: 238463.

Corral-Debrinski M, Horton T, Lott MT, Shoffner JM, Beal MF, Wallace DC. 1992. Mitochondrial DNA deletions in human brain: Regional variability and increase with advanced age. Nat Genet 2: 324-329.

Crabbe L, Verdun RE, Haggblom CI, Karlseder J. 2004. Defective telomere lagging strand synthesis in cells lacking WRN helicase activity. Science 306: 1951-1953.

Croteau DL, Rossi ML, Canugovi C, Tian J, Sykora P, Ramamoorthy M, Wang Z, Singh DK, Akbari M, Kasiviswanathan R, et al. 2012. RECQL4 localizes to mitochondria and preserves mitochondrial DNA integrity. Aging Cell 11: 456-466.

Croteau DL, Popuri V, Opresko PL, Bohr VA. 2014. Human RecQ helicases in DNA repair, recombination, and replication. Annu Rev Biochem 83: 519-552.

de Boer J, Andressoo JO, de WJ, Huijmans J, Beems RB, van SH, Weeda G, van der Horst GT, van LW, Themmen AP, et al. 2002. Premature aging in mice deficient in DNA repair and transcription. Science 296: 1276-1279.

de Souza-Pinto NC, Wilson DM III, Stevnsner TV, Bohr VA 2008. Mitochondrial DNA, base excision repair and neurodegeneration. DNA Repair (Amst) 7: 1098-1109.

Dimri GP, Lee X, Basile G, Acosta M, Scott G, Roskelley C, Medrano EE, Linskens M, Rubelj I, Pereira-Smith O, et al. 1995. A biomarker that identifies senescent human cells in culture and in aging skin in vivo. Proc Natl Acad Sci 92: 9363-9367.

Erdelyi K, Bakondi E, Gergely P, Szabo C, Virag L. 2005. Pathophysiologic role of oxidative stress-induced poly (ADP-ribose) polymerase 1 activation: Focus on cell death and transcriptional regulation. Cell Mol Life Sci 62: $751-759$.
Erol A. 2011. Deciphering the intricate regulatory mechanisms for the cellular choice between cell repair, apoptosis or senescence in response to damaging signals. Cell Signal 23: 1076-1081.

Evans MJ, Kaufman MH. 1981. Establishment in culture of pluripotential cells from mouse embryos. Nature 292: 154-156.

Fan W, Luo J. 2010. SIRT1 regulates UV-induced DNA repair through deacetylating XPA. Mol Cell 39: 247-258.

Fang EF, Scheibye-Knudsen M, Brace LE, Kassahun H, SenGupta T, Nilsen H, Mitchell JR, Croteau DL, Bohr VA. 2014. Defective mitophagy in XPA via PARP-1 hyperactivation and $\mathrm{NAD}^{+} /$SIRT1 reduction. Cell 157: 882-896.

Fatokun AA, Dawson VL, Dawson TM. 2014. Parthanatos: Mitochondrial-linked mechanisms and therapeutic opportunities. Br J Pharmacol 171: 2000-2016.

Fernandez-Checa JC, Fernandez A, Morales A, Mari M, Garcia-Ruiz C, Colell A. 2010. Oxidative stress and altered mitochondrial function in neurodegenerative diseases: Lessons from mouse models. CNS Neurol Disord Drug Targets 9: 439-454.

Fischer JM, Popp O, Gebhard D, Veith S, Fischbach A, Beneke S, Leitenstorfer A, Bergemann J, Scheffner M, Ferrando-May E, et al. 2014. Poly(ADP-ribose)-mediated interplay of XPA and PARP1 leads to reciprocal regulation of protein function. FEBS J 281: 3625-3641.

Fishel ML, Vasko MR, Kelley MR. 2007. DNA repair in neurons: So if they don't divide what's to repair? Mutat Res 614: 24-36.

Fry M, Loeb LA. 1999. Human Werner syndrome DNA helicase unwinds tetrahelical structures of the fragile $\mathrm{X}$ syndrome repeat sequence d(CGG) ${ }_{n}$. J Biol Chem 274: $12797-12802$.

Fusco D, Colloca G, Lo Monaco MR, Cesari M. 2007. Effects of antioxidant supplementation on the aging process. Clin Interv Aging 2: 377-387.

Garinis GA, van der Horst GT, Vijg J, Hoeijmakers JH. 2008. DNA damage and ageing: New-age ideas for an age-old problem. Nat Cell Biol 10: 1241-1247.

Ghosh AK, Rossi ML, Singh DK, Dunn C, Ramamoorthy M, Croteau DL, Liu Y, Bohr VA. 2011. RECQL4, the protein mutated in Rothmund-Thomson syndrome, functions in telomere maintenance. J Biol Chem 287: 196-209.

Gladyshev VN. 2014. The free radical theory of aging is dead. Long live the damage theory! Antioxid Redox Signal 20: 727-731.

Goldsmith TC. 2012. On the programmed/non-programmed aging controversy. Biochemistry (Mosc) 77: $729-732$.

Gomes AP, Price NL, Ling AJ, Moslehi JJ, Montgomery MK, Rajman L, White JP, Teodoro JS, Wrann CD, Hubbard BP, et al. 2013. Declining $\mathrm{NAD}^{+}$induces a pseudohypoxic state disrupting nuclear-mitochondrial communication during aging. Cell 155: 1624-1638.

Gonzalez-Suarez E, Flores JM, Blasco MA. 2002. Cooperation between p53 mutation and high telomerase transgenic expression in spontaneous cancer development. Mol Cell Biol 22: 7291-7301.

Gonzalo S. 2014. DNA damage and lamins. Adv Exp Med Biol 773: 377-399. 
Goto M. 1997. Hierarchical deterioration of body systems in Werner's syndrome: Implications for normal ageing. Mech Ageing Dev 98: 239-254.

Gredilla R, Bohr VA, Stevnsner T. 2010. Mitochondrial DNA repair and association with aging-An update. Exp Gerontol 45: 478-488.

Gredilla R, Garm C, Stevnsner T. 2012. Nuclear and mitochondrial DNA repair in selected eukaryotic aging model systems. Oxid Med Cell Longev 2012: 282438.

Haas RH, Parikh S, Falk MJ, Saneto RP, Wolf NI, Darin N, Cohen BH. 2007. Mitochondrial disease: A practical approach for primary care physicians. Pediatrics 120: 13261333.

Hanish JP, Yanowitz JL, de LT. 1994. Stringent sequence requirements for the formation of human telomeres. Proc Natl Acad Sci 91: 8861-8865.

Harman D. 1972. The biologic clock: The mitochondria? J Am Geriatr Soc 20: 145-147.

Hayflick L. 1965. The limited in vitro lifetime of human diploid cell strains. Exp Cell Res 37: 614-636.

Hayflick L. 2007. Biological aging is no longer an unsolved problem. Ann NY Acad Sci 1100: 1-13.

Hirano T, Yamaguchi R, Asami S, Iwamoto N, Kasai H. 1996. 8-Hydroxyguanine levels in nuclear DNA and its repair activity in rat organs associated with age. J Gerontol A Biol Sci Med Sci 51: 303-307.

Hoeijmakers JH. 2009. DNA damage, aging, and cancer. $N$ Engl J Med 361: 1475-1485.

Holliday R. 2014. The commitment of human cells to senescence. Interdiscip Top Gerontol 39: 1-7.

Hudson EK, Hogue B, Souza-Pinto N, Croteau DL, Anson RM, Bohr VA, Hansford RG. 1998. Age associated change in mitochondrial DNA. Free Radic Res Commun 29: 573 579.

Hyun M, Lee J, Lee K, May A, Bohr VA, Ahn B. 2008. Longevity and resistance to stress correlate with DNA repair capacity in Caenorhabditis elegans. Nucleic Acids Res 36: $1380-1389$.

Imai S, Guarente L. 2014. $\mathrm{NAD}^{+}$and sirtuins in aging and disease. Trends Cell Biol 24: 464-471.

Iyama T, Wilson DM III. 2013. DNA repair mechanisms in dividing and non-dividing cells. DNA Repair (Amst) 12: 620-636.

Jaskelioff M, Muller FL, Paik JH, Jiang S, Adams AC, Sahin E, Kost-Alimova M, Protopopov A, Cadinanos J, Horner JW, et al. 2011. Telomerase reactivation reverses tissue degeneration in aged telomerase-deficient mice. Nature 469: $102-106$

Jeppesen DK, Bohr VA, Stevnsner T. 2011. DNA repair deficiency in neurodegeneration. Prog Neurobiol 94: 166200.

Jin K. 2010. Modern biological theories of aging. Aging Dis 1: 72-74.

Kaneko T, Tahara S, Matsuo M. 1996. Non-linear accumulation of 8-hydroxy-2'-deoxyguanosine, a marker of oxidized DNA damage, during aging. Mutat Res 316: $277-$ 285.

Karlseder J, Broccoli D, Dai Y, Hardy S, De Lange T. 1999. p53- and ATM-dependent apoptosis induced by telomeres lacking TRF2. Science 283: 1321-1325.
Kenyon J, Gerson SL. 2007. The role of DNA damage repair in aging of adult stem cells. Nucleic Acids Res 35: $7557-$ 7565.

Khakhar RR, Cobb JA, Bjergbaek L, Hickson ID, Gasser SM. 2003. RecQ helicases: Multiple roles in genome maintenance. Trends Cell Biol 13: 493-501.

Kirkwood TB. 2005. Understanding the odd science of aging. Cell 120: 437-447.

Kraytsberg Y, Kudryavtseva E, McKee AC, Geula C, Kowall NW, Khrapko K. 2006. Mitochondrial DNA deletions are abundant and cause functional impairment in aged human substantia nigra neurons. Nat Genet 38: 518-520.

Kyng K, Croteau DL, Bohr VA. 2009. Werner syndrome resembles normal aging. Cell Cycle 8: 2323.

Lagouge M, Larsson NG. 2013. The role of mitochondrial DNA mutations and free radicals in disease and ageing. $J$ Intern Med 273: 529-543.

Lee HC, Chang CM, Chi CW. 2010. Somatic mutations of mitochondrial DNA in aging and cancer progression. Ageing Res Rev 9: S47-S58.

Li W, Vijg J. 2012. Measuring genome instability in agingA mini-review. Gerontology 58: 129-138.

Lillenes MS, Stoen M, Gomez-Munoz M, Torp R, Gunther CC, Nilsson LN, Tonjum T. 2013. Transient OGG1, APE1, PARP1 and Pol $\beta$ expression in an Alzheimer's disease mouse model. Mech Ageing Dev 134: 467-477.

Lin J, Kaur P, Countryman P, Opresko PL, Wang H. 2014. Unraveling secrets of telomeres: One molecule at a time. DNA Repair (Amst) 20: 142-153.

Lindahl T. 1993. Instability and decay of the primary structure of DNA. Nature 362: 709-715.

Liochev SI. 2014. Reflections on the theories of aging, of oxidative stress, and of science in general. Is it time to abandon the free radical (oxidative stress) theory of aging? Antioxid Redox Signal doi: 10.1089/ars.2014.5928.

Liu D, Croteau DL, Souza-Pinto N, Pitta M, Tian J, Wu C, Jiang H, Mustafa K, Keijzers G, Bohr VA, et al. 2011. Evidence that OGG1 glycosylase protects neurons against oxidative DNA damage and cell death under ischemic conditions. J Cereb Blood Flow Metab 31: 680-692.

Ljubuncic P, Reznick AZ. 2009. The evolutionary theories of aging revisited-A mini-review. Gerontology 55: $205-$ 216.

Lowell BB, Shulman GI. 2005. Mitochondrial dysfunction and type 2 diabetes. Science 307: 384-387.

Lu J, Liu Y. 2010. Deletion of Ogg1 DNA glycosylase results in telomere base damage and length alteration in yeast. EMBO J 29: 398-409.

Lustbader JW, Cirilli M, Lin C, Xu HW, Takuma K, Wang N, Caspersen C, Chen X, Pollak S, Chaney M, et al. 2004 $A B A D$ directly links $A \beta$ to mitochondrial toxicity in Alzheimer's disease. Science 304: 448-452.

Machwe A, Xiao L, Groden J, Orren DK. 2006. The Werner and Bloom syndrome proteins catalyze regression of a model replication fork. Biochemistry 45: 13939-13946.

Madamanchi NR, Runge MS. 2007. Mitochondrial dysfunction in atherosclerosis. Circ Res 100: 460-473.

Madabhushi R, Pan L, Tsai LH. 2014. DNA damage and its links to neurodegeneration. Neuron 83: 266-282. 
S. Maynard et al.

Martin GM. 2011. The biology of aging: 1985-2010 and beyond. FASEB J 25: 3756-3762.

Marzetti E, Csiszar A, Dutta D, Balagopal G, Calvani R, Leeuwenburgh C. 2013. Role of mitochondrial dysfunction and altered autophagy in cardiovascular aging and disease: From mechanisms to therapeutics. Am J Physiol Heart Circ Physiol 305: H459-H476.

Maynard SP, Miller RA. 2006. Fibroblasts from long-lived Snell dwarf mice are resistant to oxygen-induced in vitro growth arrest. Aging Cell 5: 89-96.

Maynard S, Swistowska AM, Lee JW, Liu Y, Liu ST, Da Cruz AB, Rao M, de Souza-Pinto NC, Zeng X, Bohr VA. 2008. Human embryonic stem cells have enhanced repair of multiple forms of DNA damage. Stem Cells 26: 22662274.

Maynard S, Schurman SH, Harboe C, de Souza-Pinto NC, Bohr VA. 2009. Base excision repair of oxidative DNA damage and association with cancer and aging. Carcinogenesis 30: 2-10.

Maynard S, Keijzers G, Gram M, Desler C, Bendix L, BudtzJorgensen E, Molbo D, Croteau DL, Osler M, Stevnsner T, et al. 2013. Relationships between human vitality and mitochondrial respiratory parameters, reactive oxygen species production and dNTP levels in peripheral blood mononuclear cells. Aging (Albany NY) 5: 850-864.

Maynard S, Keijzers G, Hansen AM, Osler M, Molbo D, Bendix L, Moller P, Loft S, Moreno-Villanueva M, Burkle A, et al. 2014. Associations of subjective vitality with DNA damage, cardiovascular risk factors and physical performance. Acta Physiol (Oxf) 213: 156-170.

McKinnon PJ. 2009. DNA repair deficiency and neurological disease. Nat Rev Neurosci 10: 100-112.

Mercer JR, Cheng KK, Figg N, Gorenne I, Mahmoudi M, Griffin J, Vidal-Puig A, Logan A, Murphy MP, Bennett M. 2010. DNA damage links mitochondrial dysfunction to atherosclerosis and the metabolic syndrome. Circ Res 107: 1021-1031.

Momcilovic O, Knobloch L, Fornsaglio J, Varum S, Easley C, Schatten G. 2010. DNA damage responses in human induced pluripotent stem cells and embryonic stem cells. PLoS ONE 5: e13410.

Moriwaki S, Ray S, Tarone RE, Kraemer KH, Grossman L. 1996. The effect of donor age on the processing of UVdamaged DNA by cultured human cells: Reduced DNA repair capacity and increased DNA mutability. Mutat Res 364: $117-123$.

Moskalev AA, Shaposhnikov MV, Plyusnina EN, Zhavoronkov A, Budovsky A, Yanai H, Fraifeld VE. 2013. The role of DNA damage and repair in aging through the prism of Koch-like criteria. Ageing Res Rev 12: 661-684.

Mouchiroud L, Houtkooper RH, Moullan N, Katsyuba E, Ryu D, Canto C, Mottis A, Jo YS, Viswanathan M, Schoonjans k, et al. 2013. The $\mathrm{NAD}^{+} /$sirtuin pathway modulates longevity through activation of mitochondrial UPR and FOXO signaling. Cell 154: 430-441.

Muiras ML, Muller M, Schachter F, Burkle A. 1998. Increased poly(ADP-ribose) polymerase activity in lymphoblastoid cell lines from centenarians. J Mol Med 76: 346-354.

Nakae D, Akai H, Kishida H, Kusuoka O, Tsutsumi M, Konishi y. 2000. Age and organ dependent spontane- ous generation of nuclear 8-hydroxydeoxyguanosine in male Fischer 344 rats. Lab Invest 80: 249-261.

Narendra D, Tanaka A, Suen DF, Youle RJ. 2008. Parkin is recruited selectively to impaired mitochondria and promotes their autophagy. J Cell Biol 183: 795-803.

Natale V. 2011. A comprehensive description of the severity groups in Cockayne syndrome. Am J Med Genet A 155A: 1081-1095.

Niedernhofer LJ, Bohr VA, Sander M, Kraemer KH. 2011. Xeroderma pigmentosum and other diseases of human premature aging and DNA repair: Molecules to patients. Mech Ageing Dev 132: 340-347.

Nouspikel T. 2007. DNA repair in differentiated cells: Some new answers to old questions. Neuroscience 145: $1213-$ 1221.

Osenbroch PØ, Auk-Emblem P, Halsne R, Strand J, Forstrøm RJ, van der Pluijm I, Eide L. 2009. Accumulation of mitochondrial DNA damage and bioenergetic dysfunction in CSB defective cells. FEBS J 276: 2811-2821.

Park DC, Yeo SG. 2013. Aging. Korean J Audiol 17: 39-44.

Parsons JL, Dianova II, Khoronenkova SV, Edelmann MJ, Kessler BM, Dianov GL. 2011. USP47 is a deubiquitylating enzyme that regulates base excision repair by controlling steady-state levels of DNA polymerase $\beta$. Mol Cell 41: 609-615.

Passos JF, Saretzki G, von Zglinicki T. 2007. DNA damage in telomeres and mitochondria during cellular senescence: Is there a connection? Nucleic Acids Res 35: 7505-7513.

Ramamoorthy M, Sykora P, Scheibye-Knudsen M, Dunn C, Kasmer C, Zhang Y, Becker KG, Croteau DL, Bohr VA. 2012. Sporadic Alzheimer disease fibroblasts display an oxidative stress phenotype. Free Radic Biol Med 53: 1371-1380.

Redwood AB, Perkins SM, Vanderwaal RP, Feng Z, Biehl KJ, Gonzalez-Suarez I, Morgado-Palacin L, Shi W, Sage J, Roti-Roti JL, et al. 2011. A dual role for A-type lamins in DNA double-strand break repair. Cell Cycle 10: 25492560.

Ressler S, Bartkova J, Niederegger H, Bartek J, Scharffetter-Kochanek K, Jansen-Durr P, Wlaschek M. 2006. p16INK4A is a robust in vivo biomarker of cellular aging in human skin. Aging Cell 5: 379-389.

Rhee DB, Ghosh A, Lu J, Bohr VA, Liu Y. 2011. Factors that influence telomeric oxidative base damage and repair by DNA glycosylase OGG1. DNA Repair (Amst) 10: 34-44.

Rinne M, Caldwell D, Kelley MR. 2004. Transient adenoviral $\mathrm{N}$-methylpurine DNA glycosylase overexpression imparts chemotherapeutic sensitivity to human breast cancer cells. Mol Cancer Ther 3: 955-967.

Robert L, Labat-Robert J, Robert AM. 2010. Genetic, epigenetic and posttranslational mechanisms of aging. Biogerontology 11: 387-399.

Robu M, Shah RG, Petitclerc N, Brind'Amour J, KandanKulangara F, Shah GM. 2013. Role of poly(ADP-ribose) polymerase-1 in the removal of UV-induced DNA lesions by nucleotide excision repair. Proc Natl Acad Sci 110: $1658-1663$.

Rocha CR, Lerner LK, Okamoto OK, Marchetto MC, Menck CF. 2013. The role of DNA repair in the pluripotency and differentiation of human stem cells. Mutat Res 752: 25 35 . 
Rodier F, Kim SH, Nijjar T, Yaswen P, Campisi J. 2005. Cancer and aging: The importance of telomeres in genome maintenance. Int J Biochem Cell Biol 37: 977-990.

Rodier F, Coppe JP, Patil CK, Hoeijmakers WA, Munoz DP, Raza SR, Freund A, Campeau E, Davalos AR, Campisi J. 2009. Persistent DNA damage signalling triggers senescence-associated inflammatory cytokine secretion. Nat Cell Biol 11: 973-979.

Rossi DJ, Bryder D, Seita J, Nussenzweig A, Hoeijmakers J, Weissman IL. 2007. Deficiencies in DNA damage repair limit the function of haematopoietic stem cells with age. Nature 447: 725-729.

Rossi MN, Carbone M, Mostocotto C, Mancone C, Tripodi M, Maione R, Amati P. 2009. Mitochondrial localization of PARP-1 requires interaction with mitofilin and is involved in the maintenance of mitochondrial DNA integrity. J Biol Chem 284: 31616-31624.

Rossi ML, Ghosh AK, Bohr VA. 2010. Roles of Werner syndrome protein in protection of genome integrity. DNA Repair (Amst) 9: 331-344.

Rouleau M, Aubin RA, Poirier GG. 2004. Poly(ADP-ribosyl)ated chromatin domains: Access granted. J Cell Sci 117: 815-825.

Rulten SL, Caldecott KW. 2013. DNA strand break repair and neurodegeneration. DNA Repair (Amst) 12: 558 567.

Sahin E, Colla S, Liesa M, Moslehi J, Muller FL, Guo M, Cooper M, Kotton D, Fabian AJ, Walkey C, et al. 2011. Telomere dysfunction induces metabolic and mitochondrial compromise. Nature 470: 359-365.

Sai K, Takagi A, Umemura T, Hasegawa R, Kurokawa Y. 1992. Changes of 8-hydroxydeoxyguanosine levels in rat organ DNA during the aging process. J Environ Pathol Toxicol Oncol 11: 139-143.

Samper E, Nicholls DG, Melov S. 2003. Mitochondrial oxidative stress causes chromosomal instability of mouse embryonic fibroblasts. Aging Cell 2: 277-285.

Saretzki G, Armstrong L, Leake A, Lako M, von Zglinicki T 2004. Stress defense in murine embryonic stem cells is superior to that of various differentiated murine cells. Stem Cells 22: 962-971.

Scheibye-Knudsen M, Ramamoorthy M, Sykora P, Maynard S, Lin PC, Minor RK, Wilson DM III, Cooper M, Spencer $\mathrm{R}$, de Cabo R, et al. 2012. Cockayne syndrome group B protein prevents the accumulation of damaged mitochondria by promoting mitochondrial autophagy. J Exp Med 209: 855-869.

Scheibye-Knudsen M, Scheibye-Alsing K, Canugovi C, Croteau DL, Bohr VA. 2013. A novel diagnostic tool reveals mitochondrial pathology in human diseases and aging. Aging (Albany NY) 5: 192-208.

Scheibye-Knudsen M, Fang EF, Croteau DL, Bohr VA. 2014a. Contribution of defective mitophagy to the neurodegeneration in DNA repair-deficient disorders. Autophagy 10: $1468-1469$.

Scheibye-Knudsen M, Mitchell SJ, Fang EF, Iyama T, Ward T, Wang J, Dunn CA, Singh N, Veith S, Hasan-Olive MM, et al. 2014b. A high-fat diet and $\mathrm{NAD}^{+}$activate Sirtl to rescue premature aging in cockayne syndrome. Cell Metab 20: 840-855.
Schriner SE, Linford NJ, Martin GM, Treuting P, Ogburn CE, Emond M, Coskun PE, Ladiges W, Wolf N, Van Remmen $\mathrm{H}$, et al. 2005. Extension of murine life span by overexpression of catalase targeted to mitochondria. Science 308: 1909-1911.

Sfeir A, Kosiyatrakul ST, Hockemeyer D, MacRae SL, Karlseder J, Schildkraut CL, de LT. 2009. Mammalian telomeres resemble fragile sites and require TRF1 for efficient replication. Cell 138: 90-103.

Shanley DP, Kirkwood TB. 2000. Calorie restriction and aging: A life-history analysis. Evolution 54: 740-750.

Sharma NK, Lebedeva M, Thomas T, Kovalenko OS, Stumpf JD, Shadel GS, Santos JH. 2014. Intrinsic mitochondrial DNA repair defects in Ataxia Telangiectasia. DNA Repair (Amst) 13: 22-31.

Sheng Z, Oka S, Tsuchimoto D, Abolhassani N, Nomaru H, Sakumi K, Yamada H, Nakabeppu Y. 2012. 8-Oxoguanine causes neurodegeneration during MUTYH-mediated DNA base excision repair. J Clin Invest 122: 4344-4361.

Singh DK, Ghosh AK, Croteau DL, Bohr VA. 2011. RecQ helicases in DNA double strand break repair and telomere maintenance. Mutat Res 736: 15-24.

Sobol RW, Kartalou M, Almeida KH, Joyce DF, Engelward BP, Horton JK, Prasad R, Samson LD, Wilson SH. 2003. Base excision repair intermediates induce p53-independent cytotoxic and genotoxic responses. J Biol Chem 278: 39951-39959.

Stevnsner T, Muftuoglu M, Aamann MD, Bohr VA. 2008. The role of Cockayne syndrome group B (CSB) protein in base excision repair and aging. Mech Ageing Dev 129: 441-448.

Sun H, Karow JK, Hickson ID, Maizels N. 1998. The Bloom's syndrome helicase unwinds $\mathrm{G}_{4}$ DNA. J Biol Chem 273: 27587-27592.

Sykora P, Croteau DL, Bohr VA, Wilson DM III. 2011. Aprataxin localizes to mitochondria and preserves mitochondrial function. Proc Natl Acad Sci 108: 7437-7442.

Teplyuk NM. 2012. Near-to-perfect homeostasis: Examples of universal aging rule which germline evades. J Cell Biochem 113: 388-396.

Thorslund T, von KC, Harrigan JA, Indig FE, Christiansen M, Stevnsner T, Bohr VA. 2005. Cooperation of the Cockayne syndrome group B protein and poly(ADP-ribose) polymerase 1 in the response to oxidative stress. $\mathrm{Mol} \mathrm{Cell}$ Biol 25: 7625-7636.

Tichy ED, Stambrook PJ. 2008. DNA repair in murine embryonic stem cells and differentiated cells. Exp Cell Res 314: 1929-1936.

Tillement L, Lecanu L, Papadopoulos V. 2011. Alzheimer's disease: Effects of $\beta$-amyloid on mitochondria. Mitochondrion 11: 13-21.

Tomkinson AE, Howes TR, Wiest NE. 2013. DNA ligases as therapeutic targets. Transl Cancer Res 2: 1219.

Tosato M, Zamboni V, Ferrini A, Cesari M. 2007. The aging process and potential interventions to extend life expectancy. Clin Interv Aging 2: 401-412.

Trifunovic A, Wredenberg A, Falkenberg M, Spelbrink JN, Rovio AT, Bruder CE, Bohlooly Y, Gidlof S, Oldfors A, Wibom R, et al. 2004. Premature ageing in mice expressing defective mitochondrial DNA polymerase. Nature 429: 417-423. 
S. Maynard et al.

Trivedi RN, Almeida KH, Fornsaglio JL, Schamus S, Sobol RW. 2005. The role of base excision repair in the sensitivity and resistance to temozolomide-mediated cell death. Cancer Res 65: 6394-6400.

Valentin-Vega YA, Maclean KH, Tait-Mulder J, Milasta S, Steeves M, Dorsey FC, Cleveland JL, Green DR, Kastan MB. 2012. Mitochondrial dysfunction in ataxia-telangiectasia. Blood 119: 1490-1500.

van de Ven M, Andressoo JO, Holcomb VB, von LM, Jong WM, De Zeeuw CI, Suh Y, Hasty P, Hoeijmakers JH, van der Horst GT, et al. 2006. Adaptive stress response in segmental progeria resembles long-lived dwarfism and calorie restriction in mice. PLoS Genet 2: 192.

Vendelbo MH, Nair KS. 2011. Mitochondrial longevity pathways. Biochim Biophys Acta 1813: 634-644.

Ventura-Clapier R, Garnier A, Veksler V. 2008. Transcriptional control of mitochondrial biogenesis: The central role of PGC-1 $\alpha$. Cardiovasc Res 79: 208-217.

Victor VM, Rocha M, Herance R, Hernandez-Mijares A. 2011. Oxidative stress and mitochondrial dysfunction in type 2 diabetes. Curr Pharm Des 17: 3947-3958.

Vijg J. 2008. The role of DNA damage and repair in aging: New approaches to an old problem. Mech Ageing Dev 129: 498-502.

Vijg J. 2014. Aging genomes: A necessary evil in the logic of life. Bioessays 36: 282-292.

Vina J, Borras C, Abdelaziz KM, Garcia-Valles R, GomezCabrera MC. 2013. The free radical theory of aging revis- ited: The cell signaling disruption theory of aging. Antioxid Redox Signal 19: 779-787.

von Zglinicki T. 2000. Role of oxidative stress in telomere length regulation and replicative senescence. Ann NY Acad Sci 908: 99-110.

von Zglinicki T, Burkle A, Kirkwood TB. 2001. Stress, DNA damage and ageing-An integrative approach. Exp Gerontol 36: 1049-1062.

Wallace DC. 1999. Mitochondrial diseases in man and mouse. Science 283: 1482-1488.

Wallace DC, Fan W, Procaccio V. 2010. Mitochondrial energetics and therapeutics. Annu Rev Pathol 5: 297-348.

Wang X, Michaelis EK. 2010. Selective neuronal vulnerability to oxidative stress in the brain. Front Aging Neurosci 2: 12 .

Wang Z, Rhee DB, Lu J, Bohr CT, Zhou F, Vallabhaneni H, de Souza-Pinto NC, Liu Y. 2010. Characterization of oxidative guanine damage and repair in mammalian telomeres. PLoS Genet 6: e1000951.

Weidenheim KM, Dickson DW, Rapin I. 2009. Neuropathology of Cockayne syndrome: Evidence for impaired development, premature aging, and neurodegeneration. Mech Ageing Dev 130: 619-636.

Wyman C, Kanaar R. 2006. DNA double-strand break repair: All's well that ends well. Annu Rev Genet 40: 363-383.

Youle RJ, Narendra DP. 2011. Mechanisms of mitophagy. Nat Rev Mol Cell Biol 12: 9-14.

Youle RJ, van der Bliek AM. 2012. Mitochondrial fission, fusion, and stress. Science 337: 1062-1065. 


\section{$\&_{\mathrm{CSH}}^{\infty} \&$ Cold Spring Harbor \\ $\stackrel{\text { PERSPECTTMES }}{\longrightarrow \infty_{\infty}}$ Perspectives in Medicine}

\section{DNA Damage, DNA Repair, Aging, and Neurodegeneration}

Scott Maynard, Evandro Fei Fang, Morten Scheibye-Knudsen, Deborah L. Croteau and Vilhelm A. Bohr

Cold Spring Harb Perspect Med 2015; doi: 10.1101/cshperspect.a025130 originally published online September 18, 2015

\section{Subject Collection Aging}

Personalized Financial Planning Using Applied Genetics

S. Jay Olshansky, Bradley Willcox, Kirk Ashburn, et al.

Biological Restraints on Indefinite Survival Jan Vijg and Steven N. Austad

The Role of the National Institute on Aging in the Development of the Field of Geroscience Felipe Sierra and Ronald A. Kohanski

The Funding Channels of Geroscience Stephanie Lederman

Evolutionary Approaches in Aging Research Melissa Emery Thompson

Interventions for Human Frailty: Physical Activity as a Model

Linda P. Fried

How Research on Human Progeroid and

Antigeroid Syndromes Can Contribute to the

Longevity Dividend Initiative

Fuki M. Hisama, Junko Oshima and George M. Martin

Articulating the Case for the Longevity Dividend S. Jay Olshansky
Funding Life-Extension Research

Mehmood Khan

Influence of Aging Science on Global Wealth

Management Michael Hodin

International Gains to Achieving Healthy

Longevity Andrew Scott, Julian Ashwin, Martin Ellison, et al.

From Life Span to Health Span: Declaring

"Victory" in the Pursuit of Human Longevity S. Jay Olshansky

Crowdfunding and Crowdsourcing of Aging

Science Keith Comito

Inhibition of the Mechanistic Target of Rapamycin (mTOR) - Rapamycin and Beyond Dudley W. Lamming

The Emergence of Geroscience as an Interdisciplinary Approach to the Enhancement of Health Span and Life Span Felipe Sierra

The Economic Promise of Delayed Aging Dana Goldman

For additional articles in this collection, see http://perspectivesinmedicine.cshlp.org/cgi/collection/ 